\title{
Cognitive Rigor: Augmenting Writing Skills in the EFL Classroom
}

\author{
Deepika Nelson Jihan Zayed* \\ Humanities and Administration College, Qassim Private Colleges, Buraidah, KSA
}

\begin{abstract}
Recently, educators have called for raising the expectation of students' learning through teaching more rigorous knowledge and skills. For defining and describing rigor, a cognitive rigor (CR) matrix was used in the present study to augment 12 tertiary, female, Saudi students' non-fiction writing skills in terms of organization, development, cohesion/coherence, structure, vocabulary and mechanics. The quasi-experimental design was employed using one experimental group (EG) and one control group (CG). Both groups were pre-tested and posttested in writing a non-fiction essay. The Mann-Whitney $U$ test demonstrated that there were statistically significant differences between the mean ranks of the EG and those of the CG on the post-test favoring the former. Keywords: Bloom's Taxonomy, Depth of Knowledge, cognitive rigor matrix, non-fiction, writing skills
\end{abstract} DOI: $10.7176 / \mathrm{JEP} / 10-9-10$

Publication date:March $31^{\text {st }} 2019$

\section{Introduction}

"It is time to expect more from our students," (Barack Obama, 2009). Writing is a dynamic component of students' literacy achievement, and it is a critical communication tool for them to convey opinions, describe ideas, and analyze information. Besides, in this modern hi-tech world, writing is a skill that plays an increasingly important role in success across academic and professional disciplines; word processing and other forms of electronic communication help students learn and practice writing in and out of the classroom. Consequently, the nature of writing and writing instruction is changing. That is, there is a paradigm shift in writing instruction which includes integrated interventions that involve many complementary instructional practices.

However, research piloted in the Arab world showed that EFL learners suffer from poor performance complications and low proficiency level in writing skills (Rababah, 2003; Al-Jarf, 2007; Bacha, 2010; Ezza, 2010; Javid, \& Umer, 2014). Alnufaie and Grenfell (2012), for example, conducted a study to investigate the writing strategies of 121 second-year, undergraduate Saudi students who were studying EFL in Jubail Industrial College (JIC). The writing strategies under investigation were process-oriented and product-oriented. Findings showed that $95.9 \%$ of the participants missed the two kinds of strategies.

Grami (2010) cited the results of IELTS test report of Saudi students, which revealed that they scored comparatively low in all English language skills (5.17, 4.97, 5.81 out of 9 in listening, reading and speaking respectively) but the average in writing skills was the lowest (4.83 out of 9). Al-Nofal, (2003) comprehended that when Saudi students write essays, they are generally concerned with surface aspects such as spelling, choosing vocabulary and correcting grammatical mistakes.

Al-Samadani (2010) views writing as a complex process in teaching and learning as it requires knowledge of grammar, vocabulary, writing mechanics (e.g., punctuation \& capitalization), organizational skills, style, and imagination. Fageeh (2011) claimed that, "many EFL learners heavily rely on writing as integral skill to language learning" p. 31, as supported by much research that view learners' listening, speaking and reading skills mainly depend on writing competence (e.g., Al-Ghamari, 2004; Hinkel, 2004).

The release of $A$ Nation at Risk (1983) aroused the debate about the quality of American schools. With the adoption of No Child Left Behind (2001), governors used the word "rigorous" as the adjective to describe a desired type of education. Former President George W. Bush used the term in his 2006 State of the Union Address, "We need ... to make sure those courses are rigorous enough to compete with other nations". From presidents to principals, governors to teachers, everybody tried to be either promising rigor, demanding rigor, or deploring the lack of rigor. It was concluded that academic rigor is an important part of providing the next generation with the knowledge and skills necessary to succeed in education and career.

\section{Theoretical Background}

Literally, rigor refers to "the quality of being severe or strict" while rigor mortis is "the process by which the body becomes stiff after death" (Oxford Advanced Learner's Dictionary, 1999, p. 1013). According to this definition, people may equate rigor with pain, rigid thinking, and harshness. Its association in rigor mortis gives the impression that students must suffer, as the curriculum must be narrow and deadly dull.

Yet, educationally, rigor seems to be the opposite of the dictionary meaning. With non-rigorous learning, errors are more likely to occur. Rigor is not assigning more homework. It is assigning better homework, open- 
ended work that pushes students to think in multiple ways about the tasks, and provides constructive feedback on their efforts - plus permission to edit, test prototypes, and make multiple drafts. Most important, the teacher will not accept work that is less than the students' best effort.

On May 5, 2005, the North Carolina State Board of Education (NCSBoE) passed into law High Student Performance Bill F16 requiring that all students graduate from a rigorous academic program that equips them with the knowledge, skills, and dispositions necessary to succeed in both postsecondary education and $21^{\text {st }}$-century careers. It recommended the following:

- Academic rigor is based on established expectations that ensure that all students develop the capacity to master content that is complex and challenging.

- In every subject, at every grade level, instruction and learning must include commitment to a knowledge core and application of that knowledge core to solve complex and real-world problems.

- A rigorous course is a course that examines details, insists on diligent and scrupulous study and performance, and does not settle for a mild or informal contact with the key ideas. It focuses on skills that students will be expected to master - rather than just the content they will memorize.

To sum up, academic rigor is an essential characteristic of effective curriculum, instruction, and assessment. When they are challenged, students learn to use the full range of their talents and intellectual abilities to address authentic and complex academic tasks in professional and real-life events. Academic rigor is commonly thought of in terms of three different phases in the educational process. The first is setting the standard for students; the second is equipping students through instructional and supportive methods; and the third is student demonstration of achievement. Those three phases were popularized by Barbara Blackburn's 2008 book Rigorous Schools and Classrooms: Leading the Way. She defined rigor as, "creating an environment in which each student is expected to learn at high levels, each student is supported so he or she can learn at high levels, and each student demonstrates learning at high levels." Consequently, Williamson (2012) divides this definition into:

Part I - Expecting students to learn at high levels; rigorous education begins with a belief that each student has the potential to be her or his best, no matter what.

Part II - Supporting students to learn at high levels; as students move to more challenging work, there is simultaneous scaffolding to support students. Students are not left on their own to succeed.

Part III - Ensuring students demonstrate learning at high levels; demonstrations of learning mean that instruction is not totally teacher-centered. Students should be provided with opportunities to demonstrate their learning.

To achieve rigorous academic standards, the academic, social, and developmental needs of students must be addressed. Irrespective of student's socio-economic background or educational experience, they get an opportunity to succeed at high levels. Therefore, in a report by Colvin and Jacobs (2009), a rigorous curriculum is "focused, coherent, and appropriately challenging," said William Schmidt, a Michigan State professor who studies the educational practices of countries that surpass the United States on international tests. In this report, the superintendent Jerry D. Weast mentioned that his school achieved "giving students a curriculum that will prepare them to succeed in college or the world of work," p. 3. In non-pretentious terms, students should use content knowledge about a subject to comprehend, apply, analyze, synthesize, and evaluate it. Teachers should create an environment in which each student is supported so he or she can learn at high levels.

Wyatt, Wiley, Camara, and Proestler's study (2012) was an attempt to create an index of academic rigor using self-reported course work data that would assist in providing information on the academic preparation of over one million graduating high school seniors each year. It used the SAT ${ }^{\circledR}$ Questionnaire (SAT-Q) that students completed when registering for the SAT exam to construct an academic rigor index (ARI).

Two widely accepted models for describing academic rigor: the revised Bloom's Taxonomy of Educational Objectives (2001) and Norman Webb's Depth of Knowledge (DOK) model (1997). The former categorizes the cognitive skills required of the brain when faced with a new task as it describes the type of thinking processes necessary to answer a question. The latter, on the other hand, relates more closely to the depth of content understanding and scope of a learning activity, which manifests in the skills required to complete the task from inception to finale (e.g., planning, researching, drawing conclusions). Moreover, the DOK model offers to rethink the meaning of test alignment to include both the content assessed in a test item and the depth to which students are expected to demonstrate understanding of that content.

Because no simple one-to-one correspondence relates Bloom's Taxonomy and DOK model, Hess, Jones, Carlock and Walkup (2009) combined both of them. The result was the cognitive rigor (CR) matrix, which allowed educators to examine the rigor associated with tasks that might seem at first glance comparable in complexity. Because CR encompasses the complexity of content, the cognitive engagement with that content, and the scope of the planned learning activities, the CR matrix can enhance instructional and assessment practices at the classroom level as well. The present study adapted this matrix as a means of determining the emphasis placed on each of its intersections in actual teaching non-fiction essay writing. Then, recognizing CR and analyzing its implications for instruction and assessment, the researchers tried to enhance learning opportunities for the EG 
students in an essay-writing course. That is, those treatment students were provided with a wide range of the CR matrix in augmenting their writing skills.

\section{Objectives of the study:}

In the writing class, to increase $\mathrm{CR}$ is to intensify the complexity of a text. A text is complex because of the complexity of ideas, one's confusion in the expression of thoughts (Dougherty, 2015). Focusing on the essential components of the CR matrix, the present study aimed at:

a. adapting the CR matrix to be used in improving the writing skills identified by Paulus (1999) in his rubrics (Appendix 2) in terms of organization, development, cohesion/coherence, structure, vocabulary and mechanics; and

b. exploring the effect of using CR on augmenting some non-fiction, writing skills of some EFL students who were involved in a rigorous, essay-writing course.

\section{Statement of the Problem}

Graduation from college has been associated with a wide variety of positive financial and societal outcomes. Despite several efforts made by stakeholders, syllabus designers, teachers and administrators, the Saudi students face maximum problems in their EFL writing (Al-Hazmi, 2006; Al-Khasawneh, 2010; Al-Samadani, 2010; Ezza, 2010; Grami, 2010). Specifically, at Qassim Private Colleges (QPC), the researchers observed that students did not reach the envisioned writing assessment goals by the end of each semester. That is, students at all levels are required to answer short-essay questions and write compositions which are evaluated by their teachers on the basis of their precision and excellence.

Besides, as it is intensive and comprehensible, the present research used a rigorous course to augment the expectation of some EFL students regarding their non-fiction, writing skills. In simpler terms, the adapted CR matrix was used in respect of what was imparted in addition to how it was communicated and assessed. That is, CR was introduced as an essential characteristic of effective curriculum, instruction, and assessment. Students were challenged to use the full range of their talents and intellectual abilities to address authentic and complex academic tasks writing non-fiction essays. Achieving this, the present study attempted to answer the following research questions:

1. How can the CR matrix be adapted for teaching non-fiction, writing skills?

2. What is the impact of CR on augmenting the non-fiction writing skills of EFL students?

\section{Methodology}

\subsection{Design:}

The research methodology was quasi-experimental, where both quantitative methods were employed for comparing the improvement achieved after the treatment by an experimental group (EG) and a control group (CG). Being adapted to implement rigor in the class, the CR matrix is a scale of cognitive demand (thinking) to align standards with assessments for ensuring that the content of the standard and the level of student demonstration required by that standard matches the assessment items.

\subsection{Participants:}

The sample taken for the study was 29 female students enrolled in Level 4 at the English Department, Qassim Private Colleges, KSA. Those students were distributed randomly in two groups: 12 were assigned to EG, while the other 17 to CG and both of them were taught to write an essay according to non-fiction writing skills (i.e., organization, development, cohesion/coherence, structure, vocabulary and mechanics). Both groups were asked to write an essay at the beginning and at the end of the study. The EG students were interviewed by the end of the study.

\subsection{Setting:}

During the first semester of the academic year 2017/2018, the experiment lasted for a total of ten weeks of teaching the above-mentioned writing skills. Pre- and post-tests were administered in the form of writing an essay to both groups. Both groups' scores were compared in the pre-test and the post-test.

\section{Results and Discussion}

The first research question: How can the CR matrix be adapted for teaching non-fiction, writing skills? In 2009, teachers from 200 Nevada and Oklahoma public schools submitted a collection of 200,000 samples of student homework samples, tests, quizzes, and worksheets in mathematics and English language arts for analyzing the preponderance of curricular items aligned to each cell in the CR matrix by Hess, Jones, Carlock and Walkup (2009). The present study made use of this matrix to augment 29 EFL students' non-fiction writing skills. The teacher, the first researcher, was concerned with applying a rigorous atmosphere to one of her two-section, essay- 
writing course. She taught a textbook: Effective Academic Writing 2: The Short Essay. This course familiarizes students them with forming a paragraph to a short essay in term of the ideas expressed in the introduction, the body and the concluding paragraphs. Focusing on the following will enhance writing skills: journal writing, specialized essays, and paragraph analysis.

Implementing this, the CR matrix was adapted (Appendix 1) for teaching the writing skills aimed at by this course. Originally, the CR matrix consists of 24 cells; namely, 6 levels of the revised Bloom's Taxonomy (horizontally) dichotomized into 4 levels of DOK (vertically). The teacher sorted all the instructional tasks into categories according to the adapted CR matrix; then she focused on items where the major cognitive demand was placed. For 10 weeks, 3 hours each, she taught an essay-writing course for 2 sections (EG and CG). Both groups were given some instructions on how to generate ideas in order to develop different parts of a paragraph and a well-written essay (i.e., topic sentence, an introduction paragraph, major and minor supporting sentences, and the concluding paragraph). For the latter group, she followed the objectives of the course; whereas for the former, she designed her lesson plans and classroom assessments according to the adapted matrix for a greater range of cognitive demand. That is, she provided the EG with challenging tasks and demanding goals, which enhanced both surface and deep learning of content to make sure that they could gain most from the learning opportunities she designed.

According to the 6 levels of the revised Bloom's Taxonomy, in level 1, for example, the students were gradually engaged in listing ideas or words as in a brainstorming activity prior to writing composition, or were asked to write simple sentences. In level $\mathbf{2}$, students were engaged in the first draft writing or brief extemporaneous speaking for a limited number of purposes and audiences. Students began to connect ideas using a simple organizational structure. For example, students might be engaged in note-taking, outlining or simple summaries. Text may be limited to one paragraph. In level 3, students were engaged in developing compositions that included multiple paragraphs. These compositions included complex sentence structure and demonstrated some synthesis and analysis. Students showed awareness of their audience and purpose through focus, organization and the use of appropriate compositional elements. The use of appropriate compositional elements included chronological order in a narrative or including supporting facts and details in an informational report. At this stage, students were engaged in editing and revising to improve the quality of the composition. The last level $\mathbf{4}$, the standard at this level was a multi-paragraph composition that demonstrated synthesis and analysis of complex ideas or themes. There was evidence of deep awareness of purpose and audience.

As the CR matrix is means of analyzing the emphasis placed on each of its intersections, teachers should be skilled at recognizing CR so that they can enhance learning opportunities that covers a wide range of the matrix. According to Dougherty (2015), the most common way to increase rigor in a task depends upon a number of factors like difficult and unfamiliar vocabulary and syntax or complexity of ideas, doubt and confusion in expressing thoughts.

The second research question: What is the impact of $C R$ on augmenting the non-fiction, writing skills of EFL students?

For proving the equivalence between the two groups before the treatment, the students were pre-tested writing a compare-and-contrast essay "My Two Cities". Analysis of the students' essays was based on the Paulus' rubrics (1999) (Appendix 2). Those rubrics were designed to give clear and detailed explanation of writing skills in terms of organization, development, cohesion/coherence, structure, vocabulary and mechanics according to a 1-to-10point scale. The Mann-Whitney test for small samples where $(n \leq 20)$ was used to determine the significant differences between the mean ranks of the EG and those of the CG. Table 1 shows that all the U-values are not significant at 0.05 level, which means that the two groups were equivalent. 
Table 1: U Values between the mean ranks of both EG and CG in the pre-test

\begin{tabular}{|c|c|c|c|c|c|c|}
\hline Writing Skills & Groups & n. & Mean Ranks & Sum of Ranks & $\mathrm{U}$ & Sign. \\
\hline \multirow[t]{2}{*}{ Organization } & $\mathrm{CG}$ & 17 & 16.97 & 288.50 & \multirow[t]{2}{*}{68.50} & \multirow[t]{2}{*}{0.097} \\
\hline & EG & 12 & 12.21 & 146.50 & & \\
\hline \multirow[t]{2}{*}{ Development } & $\mathrm{CG}$ & 17 & 16.18 & 275.00 & \multirow[t]{2}{*}{82.00} & \multirow[t]{2}{*}{0.312} \\
\hline & $\mathrm{EG}$ & 12 & 13.33 & 160.00 & & \\
\hline \multirow[t]{2}{*}{ Coherence/Cohesion } & $\mathrm{CG}$ & 17 & 14.18 & 241.00 & \multirow[t]{2}{*}{88.00} & \multirow[t]{2}{*}{0.461} \\
\hline & $\mathrm{EG}$ & 12 & 16.17 & 194.00 & & \\
\hline \multirow[t]{2}{*}{ Structure } & $\mathrm{CG}$ & 17 & 14.62 & 248.50 & \multirow[t]{2}{*}{95.50} & \multirow[t]{2}{*}{0.739} \\
\hline & EG & 12 & 15.54 & 186.50 & & \\
\hline \multirow[t]{2}{*}{ Vocabulary } & $\mathrm{CG}$ & 17 & 13.32 & 226.50 & \multirow[t]{2}{*}{73.50} & \multirow[t]{2}{*}{0.144} \\
\hline & EG & 12 & 17.38 & 208.50 & & \\
\hline \multirow[t]{2}{*}{ Mechanics } & $\mathrm{CG}$ & 17 & 13.71 & 233.00 & \multirow[t]{2}{*}{80.00} & \multirow[t]{2}{*}{0.213} \\
\hline & EG & 12 & 16.83 & 202.00 & & \\
\hline \multirow[t]{2}{*}{ Total } & $\mathrm{CG}$ & 17 & 14.65 & 249.00 & \multirow[t]{2}{*}{96.00} & \multirow[t]{2}{*}{0.787} \\
\hline & EG & 12 & 15.50 & 186.00 & & \\
\hline
\end{tabular}

Then, it was crucial to determine whether any improvement in students' writing occurred as a result of being involved in the treatment, so the study sample in both of the EG and CG were post-tested following the same procedures in the pre-test. Table 2 shows that all the U-values are significant at 0.05 level, which means that there were statistically significant differences between the mean ranks of the EG and those of the CG in favor of the former group. In addition, it is also clear that the values of the effect size were larger than 0.15 , indicating that the effect size of experimental treatment was significant and contributed to the total variance of writing skills by $79 \%$. Table 2: U Values between the mean ranks of both EG and CG in the post-test

\begin{tabular}{|c|c|c|c|c|c|c|c|c|}
\hline Writing Skills & Groups & n. & Mean Ranks & Sum of Ranks & $\mathrm{U}$ & Sign. & eta & Effect Size \\
\hline \multirow[t]{2}{*}{ Organization } & $\mathrm{CG}$ & 17 & 19.63 & 235.50 & \multirow[t]{2}{*}{46.50} & \multirow[t]{2}{*}{0.005} & \multirow[t]{2}{*}{0.53} & \multirow[t]{2}{*}{ great } \\
\hline & $\overline{E G}$ & 12 & 11.74 & 199.50 & & & & \\
\hline \multirow[t]{2}{*}{ Development } & $\mathrm{CG}$ & 17 & 20.13 & 241.50 & \multirow[t]{2}{*}{40.50} & \multirow[t]{2}{*}{0.003} & \multirow[t]{2}{*}{0.55} & \multirow[t]{2}{*}{ great } \\
\hline & $\mathrm{EG}$ & 12 & 11.38 & 193.50 & & & & \\
\hline \multirow[t]{2}{*}{ Coherence/Cohesion } & $\mathrm{CG}$ & 17 & 19.63 & 235.50 & \multirow[t]{2}{*}{46.50} & \multirow[t]{2}{*}{0.005} & \multirow[t]{2}{*}{0.52} & \multirow[t]{2}{*}{ great } \\
\hline & EG & 12 & 11.74 & 199.50 & & & & \\
\hline \multirow[t]{2}{*}{ Structure } & $\mathrm{CG}$ & 17 & 20.00 & 240.00 & \multirow[t]{2}{*}{42.00} & \multirow[t]{2}{*}{0.003} & \multirow[t]{2}{*}{0.55} & \multirow[t]{2}{*}{ great } \\
\hline & $\mathrm{EG}$ & 12 & 11.47 & 195.00 & & & & \\
\hline \multirow[t]{2}{*}{ Vocabulary } & $\mathrm{CG}$ & 17 & 22.88 & 274.50 & \multirow[t]{2}{*}{7.50} & \multirow[t]{2}{*}{0.001} & \multirow[t]{2}{*}{0.82} & \multirow[t]{2}{*}{ great } \\
\hline & $\mathrm{EG}$ & 12 & 9.44 & 160.50 & & & & \\
\hline \multirow[t]{2}{*}{ Mechanics } & $\mathrm{CG}$ & 17 & 22.38 & 268.50 & \multirow[t]{2}{*}{13.50} & \multirow[t]{2}{*}{0.001} & \multirow[t]{2}{*}{0.77} & \multirow[t]{2}{*}{ great } \\
\hline & $\mathrm{EG}$ & 12 & 9.79 & 166.50 & & & & \\
\hline \multirow[t]{2}{*}{ Total } & $\mathrm{CG}$ & 17 & 23.00 & 276.00 & \multirow[t]{2}{*}{6.00} & \multirow[t]{2}{*}{0.001} & \multirow[t]{2}{*}{0.79} & \multirow[t]{2}{*}{ great } \\
\hline & EG & 12 & 9.35 & 159.00 & & & & \\
\hline
\end{tabular}

This clearly indicates a major impact of CR on students' non-fiction, writing skills. In accordance of Williamson's division (2012), each student of the treatment group was expected to learn at high levels, was supported in learning at high levels, and had the opportunity to demonstrate learning at high levels. This can be due to the teacher's influence upon students was effective in directing their achievement towards learning objectives. Thompson and Wiliam (2008) confirms that, "teacher quality trumps virtually all other influences on student achievement" p. 2. Therefore, it is rightly said "a qualified teacher has the methodological competence to enable students to develop skills for creativity and understanding" (Ololube, 2006, p. 41).

Referring to Figure 1 and Figure 2, the EG showed a significant rise after the implementation of the CR matrix and the students' scores were satisfactorily good. This can be due to focusing on having a clearly-relevant and effective content, concrete, logical, and convincing supporting examples, and the appropriate use of transitional devices, referential ties, and logical connectors. In addition, the EG was trained to pay their undivided attention to the structure and vocabulary used in their sentences (e.g., tenses, parts of speech, pronouns, articles, prepositions, conjunctions, and nouns) in order to produce grammatically-correct and clear sentences. The appropriate use of mechanical devices was stressed as well. According to the aforementioned Williamson's division (2012), the final section of the training was slightly different. That is, for having the opportunity to have support and to demonstrate their work, the treatment students were divided into two groups: givers and receivers, the former was given some instructions on how to review the essays and give feedback and the latter was trained to use the feedback to revise their essays. Later, the roles were reversed. 


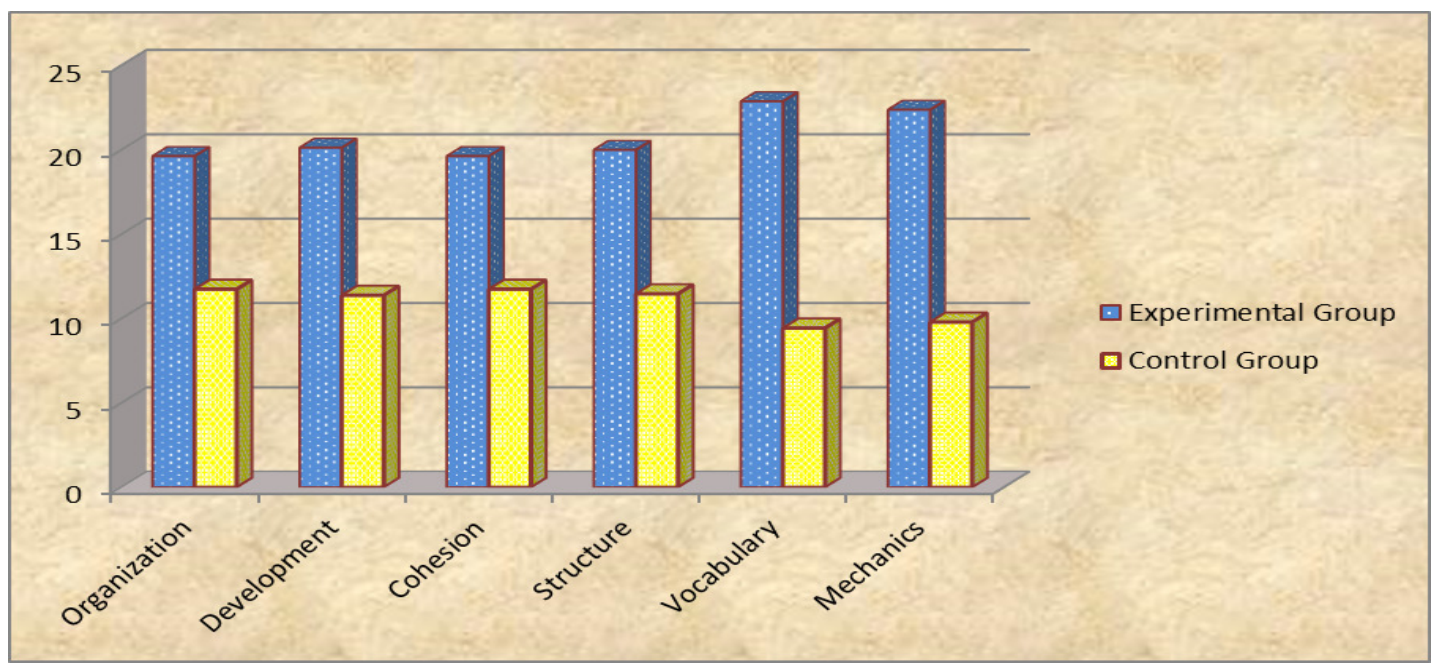

Figure 1: Mean ranks of EG and CG in the post-test

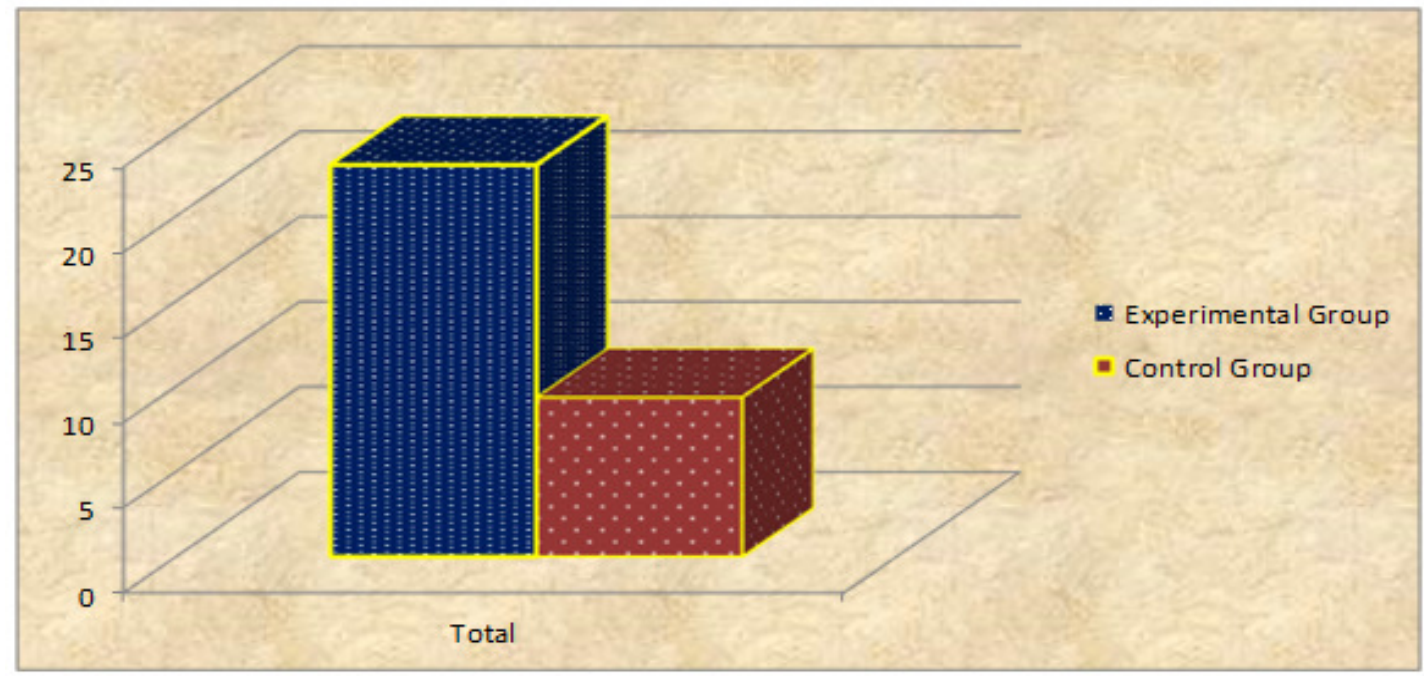

Figure 2: Mean ranks of EG and CG in the post-test total scores

Group work in the Saudi universities is still not recommended and valued because the teacher is regarded as the only one who has the knowledge. Therefore, students felt the difference of being involved in the present research. For the students, writing as a means of creating and forming ideas, and working with their peers required them to be engaged in multiple-intellectual levels. Group work was used as a tool for enhancing rigor in the class as what Rice and Hughley (1994) asserted that this work is performed by two or more people to produce and complete a text, and it includes brainstorming and generating ideas, planning and organizing, drafting, revising, and editing. Checking the EG students' reaction before and after the experiment, the second researcher interviewed some of them randomly. The results from the interview showed that the EG learners' attitudes were moderately positive; consequently, enhancing their writer's anxiety and apprehension. Before implementing rigor, one of those students' response was “Whenever I start a paragraph or an essay writing task, I face difficulty of organizing my ideas, introduction, main topic, supporting sentences for what I intend to write. I lack the ability to write a good essay". The same student, after the post-test, her attitude changed as she felt being more motivated and more positive; her grades had not only improved but she freely expressed her ideas and participated in the class: she did not have the fear.

Another student said, "I always get the idea. When I speak with a peer friend or the teacher, the idea develops from one paragraph to other... It really helps; when I speak with others I get what I need to write in the essay. But when I am writing alone, I am fixed at the topic sentence and lost ....."

Price (2004) mentions that "cognitive styles reflect the ways in which individuals process information and make sense of their world" p.683. Having raised the cognitive demands, the teacher created a "knowledgeable pressure" by asking for increasingly deeper examinations and elaborations in student work. This progression might move from a task asking for explaining a simple concept to a one requiring explaining a more complex concept. Atkinson (2004) suggests that a cognitive style is "a distinct and consistent way for an individual to encode, store 
and perform" p. 663, and is thus related to approaches in learning situations.

Students mentioned that the teacher gradually asked them to write essays from easy to difficult tasks. Namely, she gave them initially to write a paragraph about themselves 'A biography' which was at the outset not so easy to understand the organizational pattern to write a paragraph (i.e. to write a reader's attention topic sentence, supporting sentences to the main idea and an appropriate conclusion). However, with the teacher's feedback and scaffolding effort, the EG students could write a five-paragraph essay.

The EG satisfactorily felt more contented about their writing after the treatment as they were encouraged to assess their peers' essays before final submission. Tolmie et al., (2010) suggested that getting support from peers is more positive as learning tension is reduced because of the increase in mutual understanding between learning parties. Nevertheless, one student's reaction was different from those of the other interviewees; simply, she preferred writing independently, as she thought that it took a long time to finish writing essay when peers were involved.

Therefore, the findings indicated that those students who had been involved in rigorous learning had improved in all the intended aspects of writing; namely, organization, development, cohesion/coherence, structure, vocabulary and mechanics. However, they had improved more in some aspects and categories than in others. Overall, the impact was satisfactory. The attitudes and perceptions of the students had also improved as it appeared from their responses to the interview.

\section{Conclusion}

The CR matrix was used to reach the level of the expected outcomes of the non-fiction, writing skills. CR includes the basic philosophy of learning that we expect our students to demonstrate not only content mastery, but also the skills and critical thinking about the disciplines being taught. To enhance the writing skills in the EFL classroom, rigor which was introduced in the present study as a strategy to fill this need, and to raise the standards of students' achievement, which were previously showing considerable fall in their accomplishment.

Educators should use the CR matrix to align the content in their curricular materials to the instructional techniques used in classroom delivery. The CR matrix focuses on complexity of content standards to successfully complete a task. Because CR encompasses the complexity of content, the cognitive engagement with that content, and the scope of the planned learning activities, the CR matrix can enhance instructional and assessment practices at the classroom level as well.

\section{References}

Al-Ghamari, T. (2004). Integrating writing with other skills. Muscat Message, 78- 8.

Al-Hazmi, S. (2006). Writing reflection: Perceptions of Arab EFL learners. South Asian Language Review, XVI(2), 36-52.

Al-Jarf, R. (2007). Online instruction and creative writing by Saudi EFL freshman students, King Saud University, Saudi Arabia [Online]. Available: www.asian-efl journal.com

Al-Khasawneh, F. (2010). Writing for academic purposes: Problems faced by Arab postgraduate students of the college of business, UUM. ESP World, 2(9), 1-23.

Al-Nofal, A. (2003). Arabic first language writing and English second language writing processes: a comparative study. Unpublished PhD thesis, the University of Kansas.

Al-nufaie M \& Grenfell M (2012) EFL Students' writing strategies in Saudi Arabian ESP writing classes: Perspectives on learning strategies in self-access language learning, Studies in Self-Access Learning Journal, 3(4), pp. 407-422.

Al-Samadani, H. (2010). The relationship between Saudi EFL students' writing competence, L1 writing proficiency, and self-regulation. European Journal of Social Sciences, 16(1), 53-63.

Atkinson, S. (2004). A comparison of pupil learning and achievement in computer aided learning and traditionally taught situations with special reference to cognitive style and gender issues. Educational Psychology, 24(5), 695-679. doi: 10.1080/0144341042000262962

Bacha, N. (2010). Developing learners' academic writing skills in higher education: A study for educational reform. Language and Education, 16(3), 161-177. doi: 10.1080/09500780208666826

Blackburn, B. (2018). Rigor is not a four-letter word. New York: Routledge.

Colvin, R. \& Jacobs, J. (2009). Rigor: It's all the rage, but what does it mean? [Online]. In Hechinger Publications: Understanding and Reporting on Academic Rigor: A Hechinger Institute Primer for Journalists. Hechinger Institute on Education and Media, Teachers College, Columbia University. Available: http://hechinger.tc.columbia.edu/primers/Hechinger_Institute Rigor_Primer.pdf

Dougherty, E. (2015). Four ways to create a progression of rigor in your LDC tasks [Online]. Available: https://ldc.org/blog/posts/four-ways-create-progression-rigor-your-ldc-tasks

Ezza, E. (2010). Arab EFL learners' writing dilemma at tertiary level. English Language Teaching, 3(4), 33-39.

Fageeh, A. (2011). EFL learners' use of blogging for developing writing skills and enhancing attitudes towards 
English learning: An exploratory study. Journal of Language and Literature, 2(1), 31-48.

Grami, G. (2010). The effects of Integrating peer feedback into university-level ESL writing curriculum: A comparative study in a Saudi context. Doctoral dissertation submitted to Newcastle University, School of Education, Communication and Language Sciences. Available: https://theses.ncl.ac.uk/dspace/bitstream/10443/933/1/grami

Hess, K. Jones, S., Carlock, D., \& Walkup, J. (2009). Cognitive rigor: Blending the strengths of Bloom's taxonomy and Webb's depth of knowledge to enhance classroom-level [Online]. Available: https://files.eric.ed.gov/fulltext/ED517804.pdf.

Hinkel, E. (2004). Teaching academic ESL writing: Practical techniques in vocabulary and grammar. Lawrence Erlbaum Associates.

Javid, C., \& Umer, M. (2014). Saudi EFL learners' writing problems: A move towards solution. Proceeding of the Global Summit on Education GSE 2014, 4-5 March 2014. Kuala Lumpur. Malasiya.

Ololube, N. (2006). Appraising the relationship between ICT usage and integration and the standard of teacher education programs in a developing economy, International Journal of Education and Development Using
$I C T$,
2 (3),
70
85.
Available: https://www.researchgate.net/publication/229823854_Appraising_the_Relationship_Between_ICT_Usage_ and Integration and the Standard of Teacher Education Programs in a Developing Economy

Paulus, T. (1999). The effect of peer and teacher feedback on student writing. Journal of Second Language Writing, 8(3), 265-289. doi: 10.1016/S1060-3743(99)80117-9

Price, L. (2004). Individual differences in learning: Cognitive control, cognitive style, and learning style. Educational Psychology, 24(5), 681-698. doi: 10.1080/0144341042000262971

Rababah, G. (2003). Communication and linguistic problems facing Arab learners of English. Indian Journal of Applied Linguistics, 29, 127-42.

Savage, A. and Maye, P. (2006). Effective academic writing 2: The short essay. Oxford University Press.

Tolmie, A. et al. (2010) Social effects of collaborative learning in primary schools, Learning and Instruction, 20(3), 177-191. doi:10.1016/j.learninstruc.2009.01.005

Thompson, M. \& Wiliam, D. (2008). Tight but loose: A conceptual framework for scaling up school reforms. In E. Caroline Wylie Research Report, Tight but Loose Scaling Up Teacher Professional Development in Diverse Contexts. ETS, RR-08-29, 1-43. Available: https://www.ets.org/Media/Research/pdf/RR-08-29.pdf

Webb, N. (1997). Criteria for alignment of expectations and assessments in mathematics and science education. Research Monograph, 6, Council of Chief State School Officers Washington, DC Research. Available: http://facstaff.wceruw.org/normw/WEBBMonograph6criteria.pdf

Williamson, R. (2012). Rigorous schools and classrooms. Research into Practice, Education Partnerships, Inc. Available: http://files.eric.ed.gov/fulltext/ED539205.pdf

Wyatt, J., Wiley, A., Camara, W., \& Proestler, N. (2012). The development of an index of academic rigor for college readiness. Research Report, 2011-11. College Board. Available: files.eric.ed.gov/fulltext/ED561023.pdf

*Deepika Nelson is presently associated with Al Qassim Pvt Colleges, KSA. Prior to this, she worked at Haramaya University, Ethiopia. Previously she worked at University of Garyounis, Libya, having 26 years of academic and administrative experience in the field of education. Major key areas of interest are English literature, TEFL, Fiction, Drama, linguistics, Business Communication, HRM and OB. Apart from this, she has been conducting Management Development Programmes and has published 58 papers at both International/National Journals. She has published three books and presented 38 papers at International and National conferences too. She is also on the editorial board of few reputed Journals.

**Jihan Zayed is an assistant professor at Humanities and Administration College, Qassim Private Colleges (QPC), Buraidah, KSA. She got her PhD degree in TEFL from Mansoura University, Egypt. She has an extensive experience in TEFL for about 20 years. She began teaching EFL to prep students for 10 years. Then, she taught in other places including Tourism and Hospitality Faculty, Suez Canal University, Egypt and Education Faculty, Majmaah University, KSA. Her research interests include language awareness, reflection, CMC, MALL and dialogism. 
Appendix 1

Cognitive Rigor (CR) Matrix* with Examples for Augmenting Non-Fiction Writing Skills

\begin{tabular}{|c|c|c|c|c|}
\hline \multirow[b]{2}{*}{ Bloom's Taxonomy levels } & \multicolumn{4}{|c|}{ Webb's Depth-of-Knowledge Levels } \\
\hline & $\begin{array}{c}\text { Level } 1 \\
\text { Recall and } \\
\text { Reproduction } \\
\end{array}$ & \begin{tabular}{|c|} 
Level 2 \\
Skills and Concepts
\end{tabular} & $\begin{array}{c}\text { Level 3 } \\
\text { Strategic Thinking/ } \\
\text { Reasoning } \\
\end{array}$ & $\begin{array}{c}\text { Level } 4 \\
\text { Extended Thinking }\end{array}$ \\
\hline $\begin{array}{l}\text { Remember } \\
\text { Retrieve knowledge from } \\
\text { long-term memory, } \\
\text { recognize, recall, locate, } \\
\text { identify }\end{array}$ & $\begin{array}{l}\text { Recall, recite, } \\
\text { recognize, locate } \\
\text { basic facts, or } \\
\text { ideas }\end{array}$ & & & \\
\hline $\begin{array}{l}\text { Understand } \\
\text { Construct meaning, clarify, } \\
\text { para- phrase, represent, } \\
\text { translate, illustrate, give } \\
\text { examples, classify, } \\
\text { categorize, summarize, } \\
\text { generalize, infer a logical } \\
\text { conclusion, predict, } \\
\text { compare/contrast, match like } \\
\text { ideas, explain, construct } \\
\text { models } \\
\end{array}$ & $\begin{array}{l}\text { List ideas or words } \\
\text { Write simple } \\
\text { sentences } \\
\text { Describe/explain } \\
\text { how or why }\end{array}$ & $\begin{array}{l}\text { Specify and explain } \\
\text { relationships } \\
\text { Give non- } \\
\text { examples/examples } \\
\text { Make and record } \\
\text { observations } \\
\text { Summarize ideas } \\
\text { Infer or predict from } \\
\text { data or texts } \\
\text { Identify main ideas }\end{array}$ & $\begin{array}{l}\text { Explain, generalize, or } \\
\text { connect ideas using } \\
\text { supporting evidence } \\
\text { Write full composition of } \\
\text { multiple paragraphs to meet a } \\
\text { specific purpose } \\
\text { Identify themes }\end{array}$ & $\begin{array}{l}\text { Explain how concepts } \\
\text { or ideas specifically } \\
\text { relate to other content } \\
\text { domains or concepts }\end{array}$ \\
\hline $\begin{array}{l}\text { Apply } \\
\text { Carry out or use a procedure } \\
\text { in a given situation; carry out } \\
\text { (apply to a familiar task), or } \\
\text { use (apply) to an unfamiliar } \\
\text { task }\end{array}$ & $\begin{array}{l}\text { Apply punctuation, } \\
\text { capitalization, } \\
\text { tgrammar and } \\
\text { spelling rules } \\
\text { Use resources to } \\
\text { edit spelling and } \\
\text { grammar }\end{array}$ & $\begin{array}{l}\text { Write a paragraph } \\
\text { using appropriate } \\
\text { organization, text } \\
\text { structure }\end{array}$ & $\begin{array}{l}\text { Use reasoning, planning, and } \\
\text { evidence } \\
\text { Edit a final draft for meaning } \\
\text { or logical progression of } \\
\text { ideas } \\
\text { Construct complex sentences }\end{array}$ & $\begin{array}{l}\text { Illustrate how multiple } \\
\text { themes (historical, } \\
\text { geographic, social) } \\
\text { may be interrelated }\end{array}$ \\
\hline $\begin{array}{l}\text { Analyze } \\
\text { Break into constituent parts, } \\
\text { determine how parts relate, } \\
\text { differentiate between } \\
\text { relevant-irrelevant, } \\
\text { distinguish, focus, select, } \\
\text { organize, outline, find } \\
\text { coherence, deconstruct (e.g., } \\
\text { for bias or point of view) }\end{array}$ & $\begin{array}{l}\text { Identify Standard } \\
\text { English } \\
\text { grammatical } \\
\text { structures } \\
\text { Locate specific } \\
\text { information } \\
\text { contained in maps, } \\
\text { charts, tables, } \\
\text { graphs, or } \\
\text { diagrams }\end{array}$ & $\begin{array}{l}\text { Categorize, classify } \\
\text { materials } \\
\text { Select appropriate data } \\
\text { demonstration } \\
\text { Identify use of literary } \\
\text { devices } \\
\text { Identify text structure } \\
\text { of paragraph } \\
\text { Refer to sources for } \\
\text { correction } \\
\text { Take notes, or outline }\end{array}$ & $\begin{array}{l}\text { Compare information within } \\
\text { or across data sets or texts } \\
\text { Analyze and draw } \\
\text { conclusions } \\
\text { Organize/interpret data } \\
\text { Analyze author's craft or } \\
\text { viewpoint }\end{array}$ & $\begin{array}{l}\text { Analyze multiple } \\
\text { sources of evidence or } \\
\text { multiple works by the } \\
\text { same author, or across } \\
\text { genres } \\
\text { Analyze } \\
\text { complex/abstract } \\
\text { themes } \\
\text { Gather, analyze, and } \\
\text { organize information } \\
\text { Analyze discourse } \\
\text { styles }\end{array}$ \\
\hline $\begin{array}{l}\text { Evaluate } \\
\text { Make judgments based on } \\
\text { criteria, check, detect } \\
\text { inconsistencies or fallacies, } \\
\text { judge, critique }\end{array}$ & & $\begin{array}{l}\text { Connect ideas with } \\
\text { simple organizational } \\
\text { strategies } \\
\text { Construct compound } \\
\text { sentences }\end{array}$ & $\begin{array}{l}\text { Cite evidence, facts and } \\
\text { details to develop a logical } \\
\text { argument for viewpoints } \\
\text { Describe, compare, and } \\
\text { contrast } \\
\text { Use a chronological order in } \\
\text { a narrative } \\
\end{array}$ & $\begin{array}{l}\text { Apply understanding } \\
\text { in a novel way, } \\
\text { provide argument or } \\
\text { justification for a } \\
\text { viewpoint }\end{array}$ \\
\hline $\begin{array}{l}\text { Create } \\
\text { Reorganize elements into } \\
\text { new patterns/structures, } \\
\text { generate, hypothesize, } \\
\text { design, plan, construct, and } \\
\text { produce }\end{array}$ & $\begin{array}{l}\text { Brainstorm ideas, } \\
\text { concepts, or } \\
\text { perspectives } \\
\text { related to a topic or } \\
\text { a concept }\end{array}$ & $\begin{array}{l}\text { Generate conjectures or } \\
\text { hypotheses based on } \\
\text { observations or prior } \\
\text { rnowledge } \\
\text { Write summaries of the } \\
\text { main ideas or details in } \\
\text { a reading selection }\end{array}$ & $\begin{array}{l}\text { rSynthesize information } \\
\text { within one source or text } \\
\text { Develop a concept map for a } \\
\text { given text } \\
\text { Show awareness of audience } \\
\text { and purpose through focus, } \\
\text { voice, and organization } \\
\end{array}$ & $\begin{array}{l}\text { Write an analysis of } \\
\text { multiple selections, } \\
\text { identifying the } \\
\text { common theme and } \\
\text { generating a purpose } \\
\text { that is appropriate for } \\
\text { both }\end{array}$ \\
\hline
\end{tabular}

*Adapted from Hess, K. Jones, S., Carlock, D., \& Walkup, J. (2009). Cognitive rigor: Blending the strengths of Bloom's taxonomy and Webb's depth of knowledge to enhance classroom-level [Online]. Available: https://files.eric.ed.gov/fulltext/ED517804.pdf. 
Appendix 2

Essay Scoring Rubrics**

\begin{tabular}{|c|c|c|c|c|c|}
\hline Scale Organization/Unity & Development & Cohesion/Coherence & Structure & Vocabulary & Mechanics \\
\hline 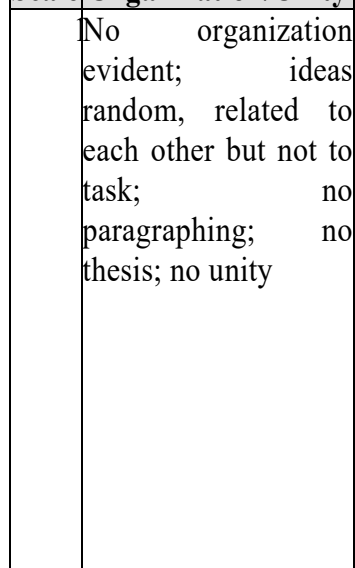 & & $\begin{array}{l}\text { Not coherent; no } \\
\text { relationship of ideas } \\
\text { evident }\end{array}$ & $\begin{array}{l}\text { Attempted } \\
\text { simple sentences; } \\
\text { serious, } \\
\text { recurring, } \\
\text { unsystematic } \\
\text { grammatical } \\
\text { errors obliterate } \\
\text { meaning; non- } \\
\text { English patterns } \\
\text { predominate }\end{array}$ & $\begin{array}{l}\text { Meaning } \\
\text { obliterated; } \\
\text { extremely limited } \\
\text { range; } \\
\text { incorrect/unsyste } \\
\text { matic inflectional, } \\
\text { derivational } \\
\text { morpheme use; } \\
\text { little to no } \\
\text { knowledge of } \\
\text { appropriate word } \\
\text { use regarding } \\
\text { meaning } \\
\text { and syntax }\end{array}$ & $\begin{array}{l}\text { Little or no } \\
\text { command of } \\
\text { spelling, } \\
\text { punctuation, } \\
\text { paragraphing, } \\
\text { capitalization }\end{array}$ \\
\hline $\begin{array}{l}\text { Suggestion of } \\
\text { organization; no clear } \\
\text { thesis; ideas listed or } \\
\text { numbered, often not } \\
\text { in sentence form; no } \\
\text { paragraphing/groupin } \\
\text { g; no unity }\end{array}$ & $\begin{array}{l}\text { Development } \\
\text { severely limited; } \\
\text { examples random, } \\
\text { if given. }\end{array}$ & $\begin{array}{l}\text { Not coherent; ideas } \\
\text { random/unconnected; } \\
\text { attempt at transitions may } \\
\text { be present, but ineffective; } \\
\text { few or unclear referential } \\
\text { ties; reader is lost. }\end{array}$ & $\begin{array}{lr}\text { Uses } & \text { simple } \\
\text { sentences; } & \text { some } \\
\text { attempts } & \text { at } \\
\text { various rra } & \text { verb } \\
\text { tenses; } & \text { serious } \\
\text { unsystematic } \\
\text { errors, occasional } \\
\text { clarity; possibly } \\
\text { uses } \\
\text { coordination; } \\
\text { meaning often } \\
\text { obliterated; } \\
\text { unsuccessful } \\
\text { attempts r at } \\
\text { embedding may } \\
\text { be evident }\end{array}$ & $\begin{array}{l}\text { Meaning severely } \\
\text { inhibited; very } \\
\text { limited range; } \\
\text { relies on } \\
\text { repetition of } \\
\text { common words; } \\
\text { inflectional/ } \\
\text { derivational } \\
\text { morphemes } \\
\text { incorrect, } \\
\text { unsystematic; } \\
\text { very limited } \\
\text { command of } \\
\text { common words; } \\
\text { seldom idiomatic; } \\
\text { reader greatly } \\
\text { distracted }\end{array}$ & \begin{tabular}{|l|} 
Some \\
evidence of \\
command of \\
basic \\
mechanical \\
features; \\
error- ridden \\
and \\
unsystematic
\end{tabular} \\
\hline $\begin{array}{l}\text { Some organization; } \\
\text { relationship between } \\
\text { ideas } \\
\text { not evident; } \\
\text { attempted thesis, } \\
\text { but unclear; no } \\
\text { paragraphing/ } \\
\text { grouping; no } \\
\text { hierarchy of ideas; } \\
\text { suggestion of unity of } \\
\text { ideas }\end{array}$ & $\begin{array}{l}\text { Lacks content at } \\
\text { abstract and } \\
\text { concrete levels; } \\
\text { few examples }\end{array}$ & $\begin{array}{l}\text { Partially coherent; attempt } \\
\text { at relationship, relevancy } \\
\text { and progression of some } \\
\text { ideas, but inconsistent or } \\
\text { ineffective; limited use of } \\
\text { transitions; relationship } \\
\text { within and between ideas } \\
\text { unclear/non-existent; may } \\
\text { occasionally use } \\
\text { appropriate simple } \\
\text { referential ties such as } \\
\text { coordinating conjunctions }\end{array}$ & $\begin{array}{l}\text { Meaning not } \\
\text { impeded by use } \\
\text { of simple } \\
\text { sentences, } \\
\text { despite } \\
\text { errors; attempts } \\
\text { at } \\
\text { complicated } \\
\text { sentences inhibit } \\
\text { meaning; } \\
\text { possibly uses } \\
\text { coordination } \\
\text { successfully; } \\
\text { embedding may } \\
\text { be evident; } \\
\text { non-English } \\
\text { patterns evident; } \\
\text { non-parallel and } \\
\text { inconsistent } \\
\text { structures }\end{array}$ & $\begin{array}{l}\text { Meaning } \\
\text { inhibited; limited } \\
\text { range; some } \\
\text { patterns of errors } \\
\text { may be evident; } \\
\text { limited } \\
\text { command of } \\
\text { usage; much } \\
\text { repetition; reader } \\
\text { distracted at } \\
\text { times }\end{array}$ & $\begin{array}{l}\text { Evidence of } \\
\text { developing } \\
\text { command of } \\
\text { basic } \\
\text { mechanical } \\
\text { features; } \\
\text { frequent, } \\
\text { unsystematic } \\
\text { errors }\end{array}$ \\
\hline $\begin{array}{l}\text { Organization present; } \\
\text { ideas show grouping; } \\
\text { may have general } \\
\text { thesis, though not for } \\
\text { persuasion; }\end{array}$ & $\begin{array}{l}\text { Underdeveloped; } \\
\text { lacks concreteness; } \\
\text { examples may be } \\
\text { inappropriate, too } \\
\text { general; may use }\end{array}$ & $\begin{array}{l}\text { Partially coherent, main } \\
\text { purpose somewhat clear to } \\
\text { reader; relationship, } \\
\text { relevancy, and progression } \\
\text { of ideas maybe apparent; }\end{array}$ & $\begin{array}{l}\text { Relies on simple } \\
\text { structures; } \\
\text { limited command } \\
\text { of morpho- } \\
\text { syntactic system; }\end{array}$ & $\begin{array}{l}\text { Meaning inhibited } \\
\text { by somewhat } \\
\text { limited range and } \\
\text { variety; often uses } \\
\text { appropriately }\end{array}$ & $\begin{array}{l}\text { May have } \\
\text { paragraph } \\
\text { format; some } \\
\text { systematic } \\
\text { errors in }\end{array}$ \\
\hline
\end{tabular}




\begin{tabular}{|c|c|c|c|c|c|}
\hline Scale Organization/Unity & Development & Cohesion/Coherence & Structure & Vocabulary & Mechanics \\
\hline \begin{tabular}{|l|} 
beginning of \\
hierarchy of ideas; \\
lacks overall \\
persuasive focus \\
and unity
\end{tabular} & $\begin{array}{l}\text { main points as } \\
\text { support for each } \\
\text { other }\end{array}$ & $\begin{array}{l}\text { may begin to use logical } \\
\text { connectors between/within } \\
\text { ideas/paragraphs } \\
\text { effectively; } \\
\text { relationship } \\
\text { between/within } \\
\text { ideas not evident; personal } \\
\text { pronoun references exist, } \\
\text { may be clear, but lacks } \\
\text { command of demonstrative } \\
\text { pronouns and other } \\
\text { referential ties; repetition } \\
\text { of key vocabulary not used } \\
\text { successfully }\end{array}$ & $\begin{array}{l}\text { attempts at } \\
\text { embedding } \\
\text { maybe evident in } \\
\text { simple structures } \\
\text { without } \\
\text { consistent } \\
\text { success; non- } \\
\text { English patterns } \\
\text { evident }\end{array}$ & $\begin{array}{l}\text { informal lexical } \\
\text { items; systematic } \\
\text { errors in } \\
\text { morpheme usage; } \\
\text { somewhat limited } \\
\text { command of word } \\
\text { usage; } \\
\text { soccasionally } \\
\text { idiomatic; } \\
\text { frequent use of } \\
\text { circumlocution; } \\
\text { reader distracted }\end{array}$ & $\begin{array}{l}\text { spelling, } \\
\text { capitalization, } \\
\text { basic } \\
\text { punctuation } \\
\end{array}$ \\
\hline $\begin{array}{l}\text { Possible attempted } \\
\text { introduction, body, } \\
\text { conclusion; obvious, } \\
\text { general thesis with } \\
\text { some attempt to } \\
\text { follow it; ideas } \\
\text { grouped } \\
\text { appropriately; some } \\
\text { persuasive focus, } \\
\text { unclear at times; } \\
\text { hierarchy of ideas } \\
\text { may } \\
\text { exist, without } \\
\text { reflecting } \\
\text { importance; some } \\
\text { unity }\end{array}$ & $\begin{array}{l}\text { Underdeveloped; } \\
\text { some sections may } \\
\text { have concreteness; } \\
\text { some may be } \\
\text { supported while } \\
\text { others are not; } \\
\text { some examples } \\
\text { may be } \\
\text { appropriate } \\
\text { supporting } \\
\text { evidence for a } \\
\text { persuasive essay, } \\
\text { others may be } \\
\text { logical fallacies, } \\
\text { unsupported } \\
\text { generalizations }\end{array}$ & $\begin{array}{l}\text { Partially coherent; shows } \\
\text { attempt to relate ideas, still } \\
\text { ineffective at times; some } \\
\text { effective use of logical } \\
\text { connectors between/within } \\
\text { groups of } \\
\text { ideas/paragraphs; } \\
\text { command of personal } \\
\text { pronoun } \\
\text { reference; partial command } \\
\text { of } \\
\text { demonstratives, deictics, } \\
\text { determiners }\end{array}$ & $\begin{array}{l}\text { Systematic } \\
\text { consistent } \\
\text { grammatical } \\
\text { errors; some } \\
\text { successful } \\
\text { attempts at } \\
\text { complex } \\
\text { structures, but } \\
\text { limited variety; } \\
\text { clause } \\
\text { construction } \\
\text { occasionally } \\
\text { successful, } \\
\text { meaning } \\
\text { occasionally } \\
\text { disrupted by use } \\
\text { of complex or } \\
\text { non-English } \\
\text { patterns; some } \\
\text { non-parallel, } \\
\text { inconsistent } \\
\text { structures }\end{array}$ & $\begin{array}{l}\text { Meaning } \\
\text { occasionally } \\
\text { inhibited; some } \\
\text { range and variety; } \\
\text { morpheme usage } \\
\text { generally under } \\
\text { control; command } \\
\text { awkward or } \\
\text { uneven; } \\
\text { sometimes } \\
\text { informal, } \\
\text { unidiomatic, } \\
\text { distracting; some } \\
\text { use of } \\
\text { circumlocution }\end{array}$ & $\begin{array}{l}\text { Paragraph } \\
\text { format } \\
\text { evident; basic } \\
\text { punctuation, } \\
\text { simple } \\
\text { spelling, } \\
\text { capitalization, } \\
\text { formatting } \\
\text { under } \\
\text { control; } \\
\text { systematic } \\
\text { errors }\end{array}$ \\
\hline $\begin{array}{l}\text { Clear introduction, } \\
\text { body, conclusion; } \\
\text { beginning control } \\
\text { over essay format, } \\
\text { focused topic } \\
\text { sentences; narrowed } \\
\text { thesis approaching } \\
\text { position } \\
\text { statement; some } \\
\text { supporting } \\
\text { evidence, yet } \\
\text { ineffective at } \\
\text { times; hierarchy of } \\
\text { ideas } \\
\text { present without } \\
\text { always } \\
\text { reflecting idea } \\
\text { importance; may } \\
\text { digress from topic }\end{array}$ & $\begin{array}{l}\text { Partially } \\
\text { underdeveloped, } \\
\text { concreteness } \\
\text { present, but } \\
\text { inconsistent; logic } \\
\text { flaws may be } \\
\text { evident; some } \\
\text { supporting proof } \\
\text { and evidence used } \\
\text { to develop thesis; } \\
\text { some sections still } \\
\text { under-supported } \\
\text { and } \\
\text { generalized; } \\
\text { repetitive }\end{array}$ & $\begin{array}{l}\text { Basically coherent in } \\
\text { purpose } \\
\text { and focus; mostly effective } \\
\text { use of logical connectors, } \\
\text { used to progress ideas; } \\
\text { pronoun references mostly } \\
\text { clear; referential/anaphoric } \\
\text { reference may be present; } \\
\text { command of } \\
\text { demonstratives; } \\
\text { beginning appropriate use } \\
\text { of } \\
\text { transitions }\end{array}$ & $\begin{array}{l}\text { Some variety of } \\
\text { complex } \\
\text { structures } \\
\text { evident, limited } \\
\text { pattern of error; } \\
\text { meaning usually } \\
\text { clear; clause } \\
\text { construction and } \\
\text { placement } \\
\text { somewhat under } \\
\text { control; finer } \\
\text { distinction in } \\
\text { morpho-syntactic } \\
\text { system evident; } \\
\text { non-English } \\
\text { patterns may } \\
\text { occasionally } \\
\text { inhibit meaning }\end{array}$ & $\begin{array}{l}\text { Meaning seldom } \\
\text { inhibited; } \\
\text { adequate range, } \\
\text { variety; } \\
\text { Appropriately } \\
\text { academic, formal } \\
\text { in lexical choices; } \\
\text { successfully } \\
\text { avoids the first } \\
\text { person; infrequent } \\
\text { errors in } \\
\text { morpheme usage; } \\
\text { beginning to use } \\
\text { some idiomatic } \\
\text { expressions } \\
\text { successfully; } \\
\text { general command } \\
\text { of usage; rarely } \\
\text { distracting } \\
\end{array}$ & \begin{tabular}{|l|} 
Basic \\
mechanics \\
under control; \\
sometimes \\
successful \\
attempts at \\
sophistication, \\
such as semi- \\
colons, colons
\end{tabular} \\
\hline $\begin{array}{l}\text { Essay format under } \\
\text { control; appropriate } \\
\text { paragraphing and }\end{array}$ & $\begin{array}{l}\text { Acceptable level of } \\
\text { development; } \\
\text { concreteness }\end{array}$ & $\begin{array}{l}\text { Mostly coherent in } \\
\text { persuasive } \\
\text { focus and purpose, }\end{array}$ & $\begin{array}{l}\text { Meaning } \\
\text { generally clear; } \\
\text { increasing }\end{array}$ & $\begin{array}{l}\text { Meaning not } \\
\text { inhibited; } \\
\text { adequate range, }\end{array}$ & $\begin{array}{l}\text { Occasional } \\
\text { mistakes in } \\
\text { basic }\end{array}$ \\
\hline
\end{tabular}




\begin{tabular}{|c|c|c|c|c|c|}
\hline Scale Organization/Unity & Development & Cohesion/Coherence & Structure & Vocabulary & Mechanics \\
\hline \begin{tabular}{|l|} 
topic sentences; \\
hierarchy of ideas \\
present; main points \\
include persuasive \\
evidence; \\
position \\
statement/thesis \\
narrowed and directs \\
essay; \\
may occasionally \\
digress from topic; \\
basically unified; \\
follows standard \\
persuasive \\
organizational \\
patterns
\end{tabular} & $\begin{array}{l}\text { present and } \\
\text { somewhat } \\
\text { consistent; logic } \\
\text { evident, makes } \\
\text { sense, mostly } \\
\text { adequate } \\
\text { supporting proof; } \\
\text { may be repetitive }\end{array}$ & $\begin{array}{l}\text { progression of ideas } \\
\text { facilitates } \\
\text { reader understanding; } \\
\text { successful attempts to use } \\
\text { logical connectors, lexical } \\
\text { repetition, synonyms, } \\
\text { collocation; cohesive } \\
\text { devices } \\
\text { may still be inconsistent/ } \\
\text { ineffective at times; may } \\
\text { show } \\
\text { creativity; possibly still } \\
\text { some } \\
\text { irrelevancy }\end{array}$ & \begin{tabular}{l|} 
distinctions in \\
morpho-syntactic \\
system; \\
sentence variety \\
evident; \\
frequent \\
successful \\
attempts at \\
complex \\
structures; non- \\
English patterns \\
do not inhibit \\
meaning; parallel \\
and \\
consistent \\
structures used
\end{tabular} & $\begin{array}{l}\text { variety; basically } \\
\text { idiomatic; } \\
\text { infrequent errors } \\
\text { in usage; some } \\
\text { attention } \\
\text { to style; mistakes } \\
\text { rarely distracting; } \\
\text { little use of } \\
\text { circumlocution }\end{array}$ & \begin{tabular}{|l|} 
mechanics; \\
increasingly \\
successful \\
attempts at \\
sophisticated \\
punctuation; \\
may \\
have \\
systematic \\
spelling errors
\end{tabular} \\
\hline $\begin{array}{l}\text { Definite control of } \\
\text { organization; may } \\
\text { show some creativity; } \\
\text { may attempt implied } \\
\text { thesis; content clearly } \\
\text { relevant, convincing; } \\
\text { unified; } \\
\text { sophisticated; uses } \\
\text { organizational } \\
\text { control to further } \\
\text { express ideas; } \\
\text { conclusion may serve } \\
\text { specific function }\end{array}$ & $\begin{array}{l}\text { Each point clearly } \\
\text { developed with a } \\
\text { variety } \\
\text { convincing types of } \\
\text { supporting } \\
\text { evidence; ideas } \\
\text { supported } \\
\text { effectively; may } \\
\text { show originality in } \\
\text { presentation } \\
\text { support; } \\
\text { logical clear } \\
\text { persuasive/convinc } \\
\text { ing progression of } \\
\text { ideas }\end{array}$ & $\begin{array}{l}\text { Coherent; clear } \\
\text { persuasive purpose and } \\
\text { focus; ideas relevant to } \\
\text { ftopic; consistency and } \\
\text { sophistication in use of } \\
\text { transitions/ referential } \\
\text { ties; effective use of } \\
\text { lexical repetition, } \\
\text { derivations, synonyms; } \\
\text { transitional devices } \\
\text { appropriate/ effective; } \\
\text { cohesive devices used to } \\
\text { further the progression of } \\
\text { fldeas in a manner clearly } \\
\text { relevant to } \\
\text { the overall meaning }\end{array}$ & $\begin{array}{l}\text { Manipulates } \\
\text { syntax with } \\
\text { attention to style; } \\
\text { generally error- } \\
\text { free sentence } \\
\text { variety; meaning } \\
\text { clear; non- } \\
\text { English patterns } \\
\text { rarely evident }\end{array}$ & $\begin{array}{l}\text { Meaning clear; } \\
\text { fairly } \\
\text { sophisticated } \\
\text { range and variety; } \\
\text { word usage under } \\
\text { control; } \\
\text { occasionally } \\
\text { unidiomatic; } \\
\text { attempts } \\
\text { original, } \\
\text { appropriate } \\
\text { choices; may use } \\
\text { some language } \\
\text { nuance }\end{array}$ & $\begin{array}{l}\text { Uses } \\
\text { mechanical } \\
\text { devices to } \\
\text { further } \\
\text { meaning; } \\
\text { generally } \\
\text { error-free }\end{array}$ \\
\hline $\begin{array}{l}\text { Highly effective } \\
\text { organizational } \\
\text { pattern for } \\
\text { convincing, } \\
\text { persuasive essay; } \\
\text { unified with clear } \\
\text { position statement; } \\
\text { content relevant and } \\
\text { effective }\end{array}$ & $\begin{array}{l}\text { Well-developed } \\
\text { with concrete, } \\
\text { logical, appropriate } \\
\text { supporting } \\
\text { examples, evidence } \\
\text { and details; highly } \\
\text { effective/ } \\
\text { convincing; } \\
\text { possibly creative } \\
\text { use of support }\end{array}$ & $\begin{array}{l}\text { Coherent and convincing to } \\
\text { reader; uses transitiona } \\
\text { devices/referential } \\
\text { ties/logical connectors to } \\
\text { create and further } \\
\text { particular style }\end{array}$ & $\begin{array}{l}\text { Mostly error- } \\
\text { free; frequent } \\
\text { success in using } \\
\text { language } \\
\text { astylistic } \\
\text { advantage; } \\
\text { idiomatic syntax; } \\
\text { non-English } \\
\text { patterns } \\
\text { evident. }\end{array}$ & $\begin{array}{l}\text { Meaning clear; } \\
\text { sophisticated } \\
\text { range, variety; } \\
\text { often idiomatic; } \\
\text { often original, } \\
\text { appropriate } \\
\text { choices; may have } \\
\text { distinctions in } \\
\text { tnuance for } \\
\text { accuracy, clarity }\end{array}$ & $\begin{array}{l}\text { Uses } \\
\text { mechanical } \\
\text { devices for } \\
\text { stylistic } \\
\text { purposes; may } \\
\text { be error-free }\end{array}$ \\
\hline $\begin{array}{l}\text { Appropriate native- } \\
\text { like standard written } \\
\text { English }\end{array}$ & $\begin{array}{l}\text { Appropriate native- } \\
\text { like standard } \\
\text { written English }\end{array}$ & $\begin{array}{l}\text { Appropriate } \text { native-like } \\
\text { standard written English }\end{array}$ & $\begin{array}{l}\text { Appropriate } \\
\text { native-like } \\
\text { standard written } \\
\text { English }\end{array}$ & $\begin{array}{l}\text { Appropriate } \\
\text { native- } \\
\text { like standard } \\
\text { written English }\end{array}$ & $\begin{array}{l}\text { Appropriate } \\
\text { native-like } \\
\text { standard } \\
\text { written } \\
\text { English }\end{array}$ \\
\hline
\end{tabular}

**SOURCE: Paulus, T. M. (1999). The effect of peer and teacher feedback on student writing. Journal of Second Language Writing, 8, 265289; as used by:

Lundstrom, K. (2006). Teaching Writing Through Peer Revising and Reviewing. All theses and dissertations, 937. Available: https://scholarsarchive.byu.edu/etd/937 